\title{
Technologies, infrastructures and migrations: material citizenship politics
}

Nina Amelung , Cristiano Gianolla , Olga Solovova \& Joana Sousa Ribeiro

To cite this article: Nina Amelung , Cristiano Gianolla, Olga Solovova \& Joana Sousa Ribeiro (2020): Technologies, infrastructures and migrations: material citizenship politics, Citizenship Studies, DOI: 10.1080/13621025.2020.1784636

To link to this article: https://doi.org/10.1080/13621025.2020.1784636

册 Published online: 02 Jul 2020.

Submit your article to this journal $\pi$

Q View related articles $\sqsubset$

View Crossmark data $[\pi$ 


\title{
Technologies, infrastructures and migrations: material citizenship politics
}

\author{
Nina Amelung $\mathbb{D D}^{\mathrm{a}}$, Cristiano Gianolla $\mathbb{D}^{\mathrm{b}}$, Olga Solovova $\mathbb{D}^{\mathrm{c}}$ \\ and Joana Sousa Ribeiro ${ }^{b}{ }^{b}$

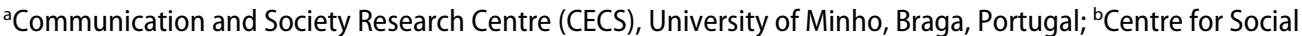 \\ Studies, University of Coimbra, Coimbra, Portugal; ' Center for Multilingualism in Society across the Lifespan \\ (Multiling), University of Oslo, Oslo, Norway
}

\begin{abstract}
This article aims to explore the multiple uses and consequences of different technologies and infrastructures in the context of migrations and how such uses and consequences inhabit and transform migrants' rights and subjectivities. It reviews relevant literature at the intersection of citizenship, critical migration studies and science and technology studies (STS), focusing in particular on the current debates underway within critical citizenship studies that examine how technologies and infrastructures shape the ability to acts of citizenship. By mobilizing insights from STS, we focus on how these political subjectivities are shaped by certain sociomaterial and epistemic practices. By introducing the notion of material citizenship politics, the article outlines a way to differentiate three different constitutive forms between technologies, infrastructures and citizenship in migrations. Technologies and infrastructures can (1) constrain acts of citizenship in migration and border regimes; (2) constitute contestation and participation over citizenship; or (3) enable and shape alternative acts of citizenship in migration and border regimes. As it provides a theoretical background to the special issue, the article also serves as the introduction to the issue.
\end{abstract}

\section{ARTICLE HISTORY}

Received 30 January 2020

Accepted 9 June 2020

\section{KEYWORDS}

Science and technology studies; sociomaterial and epistemic practices; material politics of citizenship; acts of citizenship; autonomy of migration technologies

\section{Introduction}

Technologies and infrastructures used by states, supranational institutions, international organizations and non-governmental organizations for registering, identifying and categorizing migrant subjects have increasingly transformed the migration control governance. They have also transformed those subjected to such technologies and infrastructures by restricting their ability to enact political subjectivity. However, often the very same technologies and infrastructures play also an important role for migrants themselves to claim their own rights and autonomy, either when migrants contest the existing institutional processing procedures, re-appropriate those technologies for their own good or use them to maintain their migratory autonomy. The diverse use of technologies and infrastructures in migrations and multiple enactments of political subjectivities creates tensions for constituting citizenship claims, an issue that needs to 
be fully explored and which we aim to address. How are technologies and infrastructures entangled with enacting individual and collective political subjectivities of migrant subjects and what is their impact on citizenship struggles? ${ }^{1}$

Over the last few years, citizenship studies have reexamined the themes of refugees and migration. In focus were migrant protests, a challenge for the citizenship category they contest (Tyler and Marciniak 2013; see also Topak 2017), and the 'contentious politics' of migrant and refugees as social movements (Ataç, Rygiel and Stierl 2016). Both are addressed in special issues in citizenship studies, where the contributors elaborate on the transnational character of migrants' acts and contribute to what postcolonial scholarship defines as 'intercultural translation' between migrants and non-migrants (Santos $2014,2018)$. The activist role of migrants has been further analyzed in relation to the exposure of neoliberal working regime (Oliveri 2012) and to the construction of a cosmopolitan citizenship (Caraus 2018; Topak 2017). As a result of this rethinking, citizenship has been reconsidered as a space of struggle and negotiation for social and political change.

When engaging with migration discourses, citizenship studies have also looked into the role of technology and materiality (Netz et al. 2019; Maestri and Hughes 2017; Hughes and Forman 2017). Netz et al. (2019) explored how technologies that identify migrant bodies end up shaping relational citizenship claims. Hughes and Forman (2017) have proposed that sociomaterial entanglements may exceed the apparent intentions of human subjects and may actively mediate and facilitate encounters through which political claims are made. The perspective of a material construction of citizenship touches also upon the materiality of place, such as camps and detention centers (Esposito et al. 2019; Rygiel 2011).

A few blind spots have nevertheless remained. First and foremost, scholars have yet to reflect on the societal consequences of the apparent expansion of sophisticated migration and border control infrastructures and their widening public acceptance and political normalization. What are then the implications of the technologies being used for the purpose of migration control for broader social categories - not just for those at the margins of attributed citizenship? What are the repercussions of normalizing particular values and standards in democratic societies which affect in particular vulnerable and less visible population groups? In times of the current pandemic emergency - which hits us during the finalization of this introductory article to the special issue entitled 'Material Citizenship Politics: Connecting Migration with Science and Technology Studies' - these questions become even more pressing and ambiguous as the COVID-19 effect enforces and reconfigures dilemma of visibilities and invisibilities of vulnerable populations such as people on the move (Milan, Pelizza and Lausberg 2020). For instance, digital infrastructures used for surveillance and control over the movements of the infected may in particular affect migrant subjects hard as they might need to fear discrimination or repression if that data is turned against them for migration control purposes afterwards (Milan, Pelizza and Lausberg 2020).

Second, when considering the role of technologies and infrastructures, scholars have mainly focused on those technologies and infrastructures that are employed to manage and control migration (Pelizza 2019; Pollozek and Passoth 2019). In this way, technologies used and enacted by migrants themselves have not been taken into account. We wish to complement perspectives on technologies and infrastructures of migrations by 
embracing the contrast of technologies and infrastructures aiming at migration control on the one hand and technologies and infrastructures enabling migrant subjects' autonomy on the other hand. By especially focusing on what we will call here the 'autonomy of migration technologies and infrastructures', we attempt to bring together scholarship in critical migration studies and critical citizenship studies. In order to diversify notions of technologies and infrastructures in the context of migration, we look at different technologies and infrastructures and what they do with and for migrant subjects' ability to acts of citizenship.

Addressing these research gaps, this special issue is dedicated to the multiple uses and consequences of technologies and infrastructures in the context of migration and how such uses and consequences inhabit and transform migrants' rights and subjectivities. By mobilizing insights from science and technology studies (STS), we focus on how these political subjectivities are enacted in practices that are made possible only under certain sociomaterial and epistemic conditions. With the emphasis on enactments of political subjectivities of migrant subjects, we mobilize a notion of agency which is captured here as 'the socioculturally mediated capacity to act' (Ahearn 2001). Thus, our focus lies on how migrant subject's capacity to acts of citizenship is shaped, enabled and disabled by technologies they use themselves as well as by infrastructures of migration management used to control migrants. ${ }^{2}$ By building on and expanding previous work in critical citizenship studies, we emphasize the relational dimensions of citizenship as a space of action, negotiation and struggle over migrants' identities, rights, duties and responsibilities (Isin 2019; Netz et al. 2019).

The article comes in five sections. The introduction is followed by the second section which provides an overview of the overlapping transdisciplinary research literature interested in migrations, citizenship and technologies and infrastructures. The third section portrays the constitutive components of a conceptual approach to material citizenship politics. For that purpose, we consider first different perspectives on technologies and infrastructures in migrations, and then differentiate how material citizenship politics may play out for migrant subjects. The fourth section provides an outlook on the special issue and its contributions. Finally, the fifth section is dedicated to concluding remarks on what research approach comes with a commitment to material citizenship politics beyond this special issue.

\section{Doing Migrant's rights and subjectivities with technologies and infrastructures}

Critical citizenship studies have aimed to go beyond conventional understandings of citizenship and its findings. Yet, these understandings in modern citizenship remain relevant because their norms and values become reinforced by other means - by migration control technologies and infrastructures which strongly connect identity and human rights. Conventional understandings of citizenship have established an analytical category of state membership and attributed belonging which produced findings about inclusion and exclusion as follows: 'while cast in the language of inclusion, belonging and universalism, modern citizenship has systemically made certain groups strangers and outsiders' (Isin and Turner 2002, 3). Migration control technologies and infrastructures also work to establish and consolidate citizenship categories that are de jure and de facto 
entangled in such a way that the absence of a formal citizen status implies new forms of misrecognition, restriction or lack of human rights, thus othering and discriminating people.

Apart from the dominant notion of citizenship as a legal category, Engin Isin (2019) proposed emphasizing citizenship as practice, thus opening it up conceptually to the multiple ways of doing citizenship, its enactments, performativity, in short, citizenship as 'acts of citizenship' (Isin 2012, 110). The focus on acts of citizenship is located on the various things people do - and has been so far oriented towards practices in political life, but practices of a particular kind - e.g. those practices that make them who they are and constitute themselves as political subjects through the things they do (Isin 2012, 110). Isin proposed acts of citizenship to challenge the notion of practices limited to a framework of already constituted orders of (not)attributed citizenship. In opposition, his notion of 'citizenship as acts' emphasizes the practices of those whose status is not citizenship but who still may act as if they were citizens and claim rights that they may not have. Thereby, he shifts attention in political life to practices of disruption or rupture into the political order (Isin 2012, 111).

Drawing on Isin's formulation $(2019,50)$ of 'doing rights with things', we can refer to our perspective as doing migrant's rights and subjectivities with technologies and infrastructures, as we are interested in the ways the rights and political subjectivities get enacted through technologies and infrastructures of migration management and control.

To complement the focus on the exclusionary effects produced by conventional understandings of citizenship which highlights universal principles and static relations between citizens, non-citizens and polities to which they belong, critical citizenship studies provide a distinctive and constructive approach that views citizenship as negotiation through dedicated and self-constituting practices of political subjects over rights and responsibilities. We aim to contribute to the reflection about citizenship by taking up Isin's proposition (2009) of expanding a new vocabulary of citizenship inspired by perspectives of critical migration and border studies (Casas-Cortes et al. 2015; Tazzioli and De Genova. 2015), and by focusing on the multiple enactments of technology and infrastructures for migration control and border regimes, for the mobilization against or autonomy from them (Monforte 2016; Stierl 2016). We thus contribute to the critical approaches to citizenship studies where citizenship is viewed as a dynamic category that is constantly in flux, while stressing its contestation from the margins and of the margins (Turner 2016) and dissociating it from the model of citizenship emerged within the imperial nation-states.

Building on citizenship in terms of 'acts of citizenship' (Isin 2008), i.e. 'those deeds by which actors constitute themselves (and others) as subjects of rights' (Isin 2009, 371) in the context of migration technologies and infrastructures, invites us to take a closer look at their consequences for migrants' subject positions in the first place. Thus, we explore the ways in which migrants' sociocultural practices and spaces of action can be constrained and enabled to become acts of citizenship deriving from sociotechnical and epistemic conditions, and how such conditions contribute to individuals and groups gaining recognizable positions (Hughes and Forman 2017). With this, we seek to contribute also to the ongoing project of rethinking 'citizenship after Orientalism', which implies undoing, deorientalizing and decolonizing citizenship, as well as 
uncovering and reinventing it in light of the construction of political subjectivities and their rights (Isin 2012).

For various reasons, citizenship has remained a concept treated with some 'skepticism' (Nyers 2015, 31) in critical migration studies, often referring to its legal conceptualization. Contributions to this special issue also assemble a range of different positions regarding concepts of citizenship. In order to consider categories beyond citizenship, antonym categories such as 'noncitizenship' were suggested, and the relationship between citizenship and noncitizenship explored (Tonkiss and Bloom 2015; see also Tambakaki 2015, also see Milivojevic in this issue). Noncitizenship argues for a shift from invisibility and passivity to active engagement of migrant subjects, and is not to be confused with 'non-citizenship'. While 'non-citizens' are people that lack a relationship with a specific state completely, being morally, legally and politically invisible to that state, 'noncitizens' are those who are recognized as part of such a relationship and therefore entitled to some rights and responsibility. While non-citizens are often dehumanized (morally), ignored (legally) and violated (politically and physically), 'noncitizens' are recognized, considered and dealt with as a proper category of people by the state. The category of noncitizens, in this way, pushes the political subjectivity of migrants towards claiming themselves a moral, legal and political status in the polity of transit or destination.

Yet, to undertake this analysis, this article, as well as the whole issue, looks into the politics of citizenship enacted through technologies and migration control infrastructures, Drawing from the analytical repertoire of STS, it reexamines the exclusionary logic applied to forced migrants, who are positioned as invisible or causing problems to the polity. It focuses on the sociotechnical and epistemological conditions that constrain the scope of migrants' acts of citizenship, their claiming human rights and identities. This is also relevant for broader categories of populations since, once tried out on migrants, the information management regimes and technologies aiming at surveillance and control can be extended towards citizens in general. Thus, they shape citizenship politics through the normalization of implicit normative values and paradigms linked to the construction of suspicion about otherness (Lemberg and Haioty in this issue) and modes of surveillance prone to repurpose the use of a technology beyond its original aim, potentially invading human rights. By employing conceptual inputs from STS, the issue exposes the often tacit imposition of norms and values inscribed and mobilized by such technologies and their underlying ontologies. It also makes a case for the study of the impact of those norms and values beyond the sitespecific technologies and infrastructures.

Positioned at the intersection of critical citizenship studies, critical migration studies, and STS, this issue aims to advance the conceptual and analytical repertoire by further delving into the notion of material citizenship. It leverages a focus on the sociomaterial and epistemic conditions of technologies and infrastructures, in order to understand how these determine migrant subjects' practices aiming towards the access to an attributed citizenship status, but also how they constrain acts of citizenship thus shaping multiple forms of migrants as political subjects. In such a way, this issue aims to make a valuable contribution to the current debates within critical citizenship studies that focus on the enactments and acts of citizenship, to help re-define the current notions of the political and of the political community. 


\section{Towards a material citizenship politics: bringing together migration, citizenship and materiality}

This section is dedicated to introducing the conceptual propositions of the heuristic of material citizenship politics. We do so in three steps: First, by reviewing basic assumptions borrowed from STS inspiring our approach; second, by discussing the notions of technology and infrastructures at stake in this issue, and, third, by introducing conceptual propositions of three different constitutive forms of material citizenship politics between technologies, infrastructures and citizenship in migrations.

The areas of study mobilized in this article, e.g. critical migration studies, critical citizenship studies and science and technology studies, seem to be converging in their joint interest in reexamining the identity-making phenomena entangled with sociomaterial and epistemic practices, citizenship and politics. Such shared interests may throw some light on the multiple ways in which sociomaterial entanglements and artefacts such as passports, borders, mobile phones, life vests, rescue boats, data infrastructures and biometric identification technologies reconfigure and redefine migrants' identities and their access to rights and obligations. That is why a proper consideration of the conceptual components towards an approach to material citizenship politics seems overdue.

To embark on this, we build on several fundamental assumptions from STS, including the principle of symmetry between human and non-human actors (in Actor Network Theory, Callon 1986) as well as symmetry between false/true knowledge claims (in the sociology of scientific knowledge, Bloor 1991). Furthermore, we follow a relational approach prominent in STS which acknowledges multiplicities, interdependencies and contingencies as a starting point of inquiry (Bowker and Star 1999; Latour and Woolgar 1986; Law 2004; Mol 2003). By advancing approaches inspired by Foucault (1973) yet with new conceptual and methodological commitments, STS scholars overcome criticism of the dispositive ${ }^{3}$ as a too static account for the empirical messiness/complexity (Law 2004, 5 f). Taking inspiration from Mol (2003), we assume the multiple articulations of technologies and infrastructures in migration contexts which can be enacted in various constellations and thereby generating multiple versions - instead of pre-given notions of them in relation to humans. However, these different enactments of technologies and infrastructures may get in tension and conflict with each other.

A major assumption in STS is the distribution of agency and the principle of symmetry between human and non-human actors. Thus, the agency is not restricted to people and becomes assigned to sociomaterial technologies and infrastructures endowed with complex intentions. It derives from interaction with non-human actors and is mobilized through purpose-driven practices (Lynch and Woolgar 1990; Latour and Woolgar 1986; Knorr-Cetina 1981). Since often in this context we deal with information-based technologies and infrastructures, we need to take into account the increasing scientization and technologization of migration management itself, where biometric sciences and technologies for identification of migrants play a prominent role. For this reason, we consider sociomaterial and epistemic practices related to technologies and infrastructures equally relevant to contributing to the political orders that impact on migrant subjects' ability to acts of citizenship (Voß and Freeman 2016). ${ }^{4}$ 
By relying on STS traditions committed to such relational approach, we agree with Netz et al. $(2019,238)$ that such option if/when applied in the field of migrations, has methodological consequences for the research on citizenship claims. It requires an empirically situated analysis of the technologies and infrastructures' put in practice in a concrete configuration. There are multiple ways in which migration technologies and infrastructures become to matter for acts of citizenship of migrant subjects. But there are also multiple ways how citizenship and migration technologies and infrastructures are co-produced in practice.

\subsection{Technologies and infrastructures in migrations}

Technologies and infrastructures can play out multiple and potentially contradictory forms on citizenship matters in migrations. We portray the role of sociomaterial and epistemic practices in this context from two perspectives, depending on the technologies at stake. We contrast what we will call migration control technologies and infrastructures versus autonomy of migration technologies and infrastructures.

We begin with the first perspective, i.e. a post-Foucauldian perspective on the material dimensions of controlling citizenship (Netz et al. 2019) that treats sociomaterial and epistemic entanglements of migration control technologies and infrastructures as potentially coming with tacit, constraining and constituting forces. It focuses on specific technologies and infrastructures of controlling migration, e.g. old state administrative techniques of identification and access to formal citizenship status like passports, fingerprints and border posts and lines which nowadays co-exist with the new sociotechnical technological information systems like biometric identification technologies of facial recognition and iris scan, data networks, e-border gates and other material settings that regulate people's mobility. Together, they represent relatively fixed infrastructures similar to transport systems, energy supplies and communication networks and more often operate on the transnational scale, resulting from the ongoing 'reterritorialisation' of states (Brenner 1999) - a process when some of the functions formerly executed by the states get increasingly delegated to lower (regional) or upper (transnational and international) levels.

The 'reterritorialisation' of states brings about consequences for understanding sites of citizenship struggles, as we face the overlapping and conflicting uses of institutions, laws and traditions that mobilize notions of citizenship. However, as Brenner (1999) and Jessop (1994) clarify, this does not mean that state territoriality has lost its significance altogether: national scale of state governance is rather being redefined on sub-national and supranational scales through the creation of qualitatively new institutions and regulatory forms that pursue the aim of 'ever-faster turnover times' (Brenner 1999, 435). In this sense, the newly emerged sociotechnical infrastructures of migration control sharpen the modern regulatory logic of old empires by making the processing of flows of people and goods more expansive and seemingly more efficient. Like in colonial societies, access to, control over and consequences deriving from these technologies and infrastructures are marked by power inequalities. The migration control technologies and infrastructures reside in positioning people differently and registering their inequality, thus having immediate identity-shaping potential and implications for the ability to perform acts of citizenship (Yuval-Davies 2006). Increasingly, human bodies are being 
considered as targets of such technologies and infrastructures and thus as biopolitical sites, not only because they are being subjected to several forms of social oppression (colonialism, heteropatriarchy and capitalism) but also because they are perceived as carriers of biometric identifiers, such as fingerprints, facial and iris scans (Amoure 2006). Moreover, as the processing procedures are delegated to virtual and electronic spaces and digital devices, they redirect the associated symbolic violence from concrete state agents to the entities of the 'migration machine' (Dijstelbloem and Meijer 2011). By partially redistributing the power of decisions from humans to technical artifacts and data networks, technologies and infrastructures used for migration control move any kind of protest or resistance from a moral plane to a technical one thus rendering the struggle difficult or almost impossible. Another effect of this action is that migrant subjects are relegated to 'people being processed' thus depriving them of their personal stories, ambitions and trajectories (Scheel 2019; Pelizza 2019). Thus, technologies and infrastructures in the name of migration control come with monitoring and disciplining consequences for migrant subjects, restricting and redefining their acts of citizenship and their identities as political subjects.

Technologies and infrastructures have been embraced in the context of critical migration studies in a particular way. Inspired by Brian Larkin's definition of infrastructures as 'matter that enables the movement of other matter' (Larkin 2013, 329), Xiang and Lindquist define 'migration infrastructures' as 'the systematically interlinked technologies, institutions, and actors that facilitate and condition mobility' (Xiang and Lindquist 2014, 124). Migrants are 'escorted and encapsulated from the beginning until the end of the migration circuit' (Xiang and Lindquist 2014, 131). In line with such understanding, STS-inspired takes on 'infrastructure' have developed further to focus on the informational, logistical and often invisible dimensions of infrastructures in migration control including deportation management. By bringing together critical studies of infrastructure and migration and deportation studies, Walter $(2017,2)$ has introduced the concept 'deportation infrastructure' to refer to the movement of deportees and in particular the mechanisms, procedures, vehicles, which constitute the infrastructure of forced mobility. Thereby, he defines 'the systematically interlinked technologies, institutions and actors that facilitate and condition the forced movement of persons who are subject to deportation measures, or the threat of deportation' (Walters 2017, 5). The innovation of his proposition lies in the ability to make strategic and systematic conditions of deportation infrastructure including the implementation deficits/surplus of deportation regimes visible. As a consequence, this perspective helps to expand the scope of where to look for resistance (Walters 2017,8) as we pick up with our conceptual proposition to look at technologies and infrastructures not only mobilized for migration (including detention) control and management, but potentially also enabling migrants for resistance or alternative imaginations contesting dominant political orders as the autonomy of migration technologies and infrastructures (see below).

Pollozek and Passoth (2019) approached infrastructures in the context of hotspot systems as technical apparatuses that are set up to produce specific 'logistics of mobility' (Mezzadra 2017), observing the role of devices, technologies, databases and categories to enact specific 'data identities'. Thereby the management of 'data doubles' and migrants as a form of organizing the mobility of people and data revealed modes of infrastructuring migrants throughout the logistical processing of identities (Pollozek and Passoth 2019). 
Pelizza (2019) has focused on the EU data infrastructures for population management in the context of migration control. By building on Bowker and Star (1999), the author emphasized the enactment of data identities according to specific classifications which expect applicants 'to fit into categories and categorical values inscribed in information systems and administrative templates' (Pelizza 2019, 277).

While such notions of technology and infrastructure emphasize the sociomaterial and epistemic influences of migration and border management on shaping, constraining and containing migrant's mobilities and identities, this does not mean that they are uncontestable and people cannot interact with them. While some authors have argued in favor of humanizing or democratizing migration control technologies and infrastructures, which includes making accountable the communities of practice involved in their design and implementation (see van der Kist and Rosset in this issue), others have highlighted migrant's own forms of engagement with them. The latter can be approached through the literature studying the autonomy of migration which highlights an understanding of migrant political agency. ${ }^{5}$ The autonomy of migration perspective has consistently insisted on the analysis of migratory movements as exercising a significant measure of autonomy (Papadopoulos and Tsianos 2013; Mezzadra 2011). Scholars in this realm explore how migrant subjects still find ways to resist the dehumanizing action of migration control infrastructures, trying to trick, subvert, sabotage or re-appropriate the processing devices, take their action into their own hands, incorporating them into their own narratives (Scheel 2013; 2019). In short, spaces of contestation and resistance can emerge from this interaction with technologies and infrastructures controlling migration. Papadopoulos and Tsianos have outlined the initially problematic view of autonomy of migration scholars on citizenship: de jure citizenship would '[operate] as a wall when it represents the ultimate horizon of political practice and social analysis' (Papadopoulos and Tsianos 2013, 179). In this vein, the de jure citizenship is considered as a 'bordered concept, responsible for the ongoing exclusions at the local, national and global levels of politics' (Nyers 2015, 24). However, we propose that researchers should collect these stories of contestation and resistance, make them visible by revealing the tensions underlying the relation of the 'people being processed' as migrant subjects with infrastructures and instituted forms of citizenship.

The second perspective differs with regards to the focus on which technologies and infrastructures are at stake and whose capacity to act is enabled. However, it is likewise informed by the autonomy of migration register. In contrast to the first technocratic scenario, which posits that the functioning of technologies and infrastructures lies largely beyond the control of the people whose identities and trajectories they reconfigure, the second perspective takes an innovative perspective and explores those technologies and infrastructures which may entitle migrant subjects and collectives to act as what we call here autonomy of migration technologies and infrastructures. Thereby, they enable migrant subjects not only to reclaim the autonomy of migration, but also to approach citizenship as 'creative processes that is generative of new worlds, identities and modes of belonging' (Nyers 2015, 34). The second perspective therefore embraces also those approaches which Peter Nyers invited to enhance a purely legal understanding of citizenship as often dominating in the autonomy of migration literature. Thus, it underlines the primacy of mobility and migrant subject's independence instead of the governance of border control and surveillance. It reinstates the importance of migrants' voices and subjectivities with their own decision-making, motivations, strategies 
and resistances and political agency beyond an attributed de jure citizenship frame, thereby reappropriating citizenship categories.

Authors at the intersection of critical migration studies and STS have provided examples of how technologies and infrastructure work can have enabling effects on migrants' identities, either in form of care work for the recognition of migrants' identities or in form of actual mobility infrastructures supporting autonomous mobility of migrants. M'charek and Casartelli (2019), for instance, have explored how the configuration and care for infrastructures carried out mainly by volunteers - in their case a forensic infrastructure that helps to identify drowned migrants in the Mediterranean Sea - produces acknowledgement of migrants as citizens post-mortem. Latonero and Kift (2018) have argued in favor of a new digital infrastructure for migrant's global movements. Solidarity between and with migrants is the ontological locus of the struggle for citizenship (Ataç, Rygiel and Stierl 2016; Papadopoulos and Tsianos 2013; Rygiel 2011, 2016). This approach is at odds with the criminalization of solidarity with migrants, also characterized as 'containment through rescue' situations that imply 'substantial disruptions and decelerations of migrant movements' (Tazzioli 2018, 8; see also Tazzioli and Walters 2019, Esposito et al. in this issue). Humanitarianism - as one site of intervention of states and international organizations and paradigm mobilized to justify migration control - is occasionally rejected by migrants as undermining the construction of their political subjectivity (Moulin \& Thomaz 2016). Attempts to constitute inter-subjective perspectives on acts of citizenship have included experiments with artwork (Lewicki 2017) and acts of digital citizenship (Couldry et al. 2014). Fredy Mora-Gamez (in this special issue) proposes the term 'alternative infrastructures' to acknowledge the production of alternative materiality beyond instituted migration control technologies and information infrastructures. By looking into sociomaterial practices of commemorating and sewing, which allow migrants to challenge the boundaries of instituted forms of participation and recognition, he explores what he calls 'alternative infrastructures' that challenge the instituted migration control infrastructures. Those alternative infrastructures co-constitute distinctive notions of justice achieved in daily practices based on cooperation, psychosocial support and everyday transformations and enable acts of citizenship. Our proposal is to investigate the autonomy of migration potential of technologies and infrastructures enabling migrant subjects to acts of citizenship which cannot be attributed per se to specific technologies and infrastructures but which can be further assessed through situated empirical and theoretical exploration.

\subsection{Material citizenship politics}

As shown in the previous sections, our approach to material citizenship politics builds on a combination of the critical citizenship theory (Isin 2008) with the autonomy of migration concept (Papadopoulos and Tsianos 2013; Mezzadra 2015) which is sensitive to approaching citizenship as a 'dynamic institution of domination and empowerment' (Isin 2009, 384). Our take on politics is inspired by the reflection on its role in technoscience (Papadopoulos 2010) that contributes to constituting a situated perspective that identifies with the marginalized or neglected experiences in the technoscience of migrations. This special issue takes sociomaterial and epistemic practices into account in a way considering the multiple forms of how enacting technologies and infrastructures 
enable, constrain and shape human agency, including beyond human intent, and sometimes even beyond their awareness (Jacobsen 2015). We focus on how material citizenship politics play out on migrant subjects and their political subjectivities. Such sociomaterial conditions are often the silent, normalized and naturalized 'objects' that make their political dimension and implications more difficult, yet ever more important, to grasp and understand.

Studying material citizenship politics in migration contexts makes us focus on how enactments of technologies and infrastructures impact on multiple, potentially contradictory or ambiguous, acts of citizenship (Isin 2009) shaping migrant identities, claims and rights. Therefore, we are interested in studying how sociomaterial and epistemic entanglements can (1) constrain (control, discipline, punish, contain) acts of citizenship in migration and border regimes; (2) constitute contestation and participation over 'citizenship'; or (3) enable and shape alternative acts of citizenship in migration and border regimes. Further on, we will elaborate on the three ways of material citizenship politics.

First, the constraining impact has been classified as material sub-politics in a postFoucauldian sense of configuring political subjects in a sub-discursive informal and silent manner (Marres and Lezaun 2011), often with a 'knowledge-related material dimension of migration management' in the context of information management (Pelizza 2019, 3) and through the particular ontologies of political orders (polities) associated with the normalization of values linked to control, discipline and punishment beyond the targeted groups. The constraining impact on the ability of acts of citizenship derives from technologically generating and assembling non-publics (Dijstelbloem and Broeders 2015). Non-publics are 'lost in categorization' of migration control technologies and databasing logics and differ substantially in the degree to which they could be classified as a public (Dijstelbloem and Broeders 2015, 32). Non-publics then prevent publics to emerge which in contrast could assemble as a collective around shared issues and thus articulate how technologies and infrastructures do matter and come with constraining consequences for migrant subjects disabling acts of citizenship.

Second, the contestation and participation impact occurs when technologies, infrastructures, or sociomaterial and epistemic settings become politicized or contested with regards to particular enactments which influence migrant subjects as political individuals or collectives. This highlights not only all those sociomaterial and epistemic settings that potentially become a matter of collective public concern (Marres 2012; Dewey (1990 [1922]), Lippmann (1997 [1922])), but also is a call for inclusion into the description of politics the views and claims of those affected by technologies migrant subjects and collectives. Looking at the contestation and participation impact sharpens the awareness as to how technologies and infrastructures themselves can become a site of political action through reconsidering settings for political disagreement (Marres and Lezaun 2011). Technologies and infrastructures may provide a locus for problematization of the human and non-human relations at stake and for the possibility of politics (Walters 2014).

Finally, the impact of enabling and shaping acts of citizenship brings into focus new forms of political agency of migrants themselves and actors in solidarity with migrants. It describes how migrant subjects and collectives enact citizenship in an alternative way to those of dominant migration and border regimes. Alternative or interventionist technologies and 'oppositional infrastructures' (Snodgrass 2017) can be seen as dynamic ongoing experiments, and forms of improvising with alternative imaginations, interpretations and 
articulations of noncitizenship and as self-nominated and autonomous acts of citizenship.

\section{Outlook on the special issue}

The contributors to the special issue provide a range of case studies on the role of technologies and infrastructures in determining the access to a citizenship status, constraining acts of citizenship, and shaping and enabling migrants' rights and political subjectivities.

As we aim to provide insights towards a comprehensive analytical-methodological approach on the varieties of material citizenship politics in migrations, we seek to understand how to empirically embrace this task. Although most of the articles in this special issue are dedicated to exploring the impact on migrants' individual or collective rights and subjectivities deriving from sociomaterial and epistemic practices entangled with technologies and infrastructures, they mobilize different methods for this. First, various authors explore migrants' views on the constraints on acts of citizenship deriving from control technologies and infrastructures. Esposito, Murtaza, Peano and Vacchiano, for instance, use life stories and trajectories of migrants (two Pakistani men coming to Portugal and a Nigerian woman moving to Italy) in order to explore the 'archipelago of detention', or the techniques adopted by states, international organization and civil society organizations to enact migration containment. Moulin and Magalhães interviewed migrants, institutional agents and civil society representatives, and made fieldwork observation in the areas where migration control centres are built by the Brazilian state.

Second, other authors are interested in assembling alternative or counter-narratives of migrants in distinction to dominant narratives entangled with migration control regimes. Mora-Gamez draws on a multisited ethnography to identify stories of people through the analysis of the materiality of goods that allow them to create an alternative narrative to state's reparation in Colombia and to solidarity with asylum seekers in Greece. By drawing on impacting cases of information spread from a bottom-up perspective in a range of countries, Milivojevic highlights the potential for the construction of counternarratives that contribute to the humanization of noncitizens.

Third, some authors explore how migrant subjects' views tend to be absent in the development, implementation and appropriation of technologies. Van der Kist and Rosset used a range of methods: analysis of official documents (reports, procedural and methodological guidelines, promotional material) and online materials as well as those produced by civil society, and enrich this information with interviews and field observation notes. Lemberg-Pedersen and Haioty analyse publicly available documents and build on fieldwork visit to refugee camps and to the UNHCR registration facility in Amman and Copenhagen. By doing so, they underline the imposed passivity of refugees in disputing the infrastructure through which their acts of citizenship are enacted, as if they refuse to comply with iris-scan they are treated with suspicion and excluded by the exceptional citizenship of the camp.

Beyond methodology, the authors in this special issue illustrate in manifold ways the doing of migrant subject's rights and subjectivities. Some of them highlight the resilience and resistance by migrants and their strategies to enact sociomaterial acts of citizenship. Mora-Gamez reflects on the responses of migrants, and how their acts (of citizenship) 
comply and resist the containment they are forced to face. Lemberg-Pedersen and Haioty describe how refugees, by making their iris scan available, become entitled to formal rights and duties within a camp and thus are provided with a citizenship status in a state of exceptionality, as opposed to the modern conception of citizenship as a political locus of a full right holder within the state. Esposito, Murtaza, Peano and Vacchiano approach migrant's subjectivity from the perspective of the victims of containment infrastructure, and, in solidarity with them, underline the relevance of fragmented citizenship and make visible the materiality of containment. Esposito et al. focus on migrants who are abused, violated or included in hosting societies in different ways. The category of noncitizen, as opposed to non-citizen (see above), is further developed by Milivojevic. The author argues that the political subjectivity of migrants is reinforced by their capacity to build counter-narratives to those who represent migrants as a threat for democracy. These do not only help construct empathy and solidarity with the people on the move but also provide them with an agentive dimension on which a noncitizenship can be created. Moulin and Magalhães provide the case of response by migrants who refuse to comply with the time management and discipline imposed upon them by the migration control infrastructures, a position that the Venezuelans in Brazil hold in non-confrontational terms. Unlike Lemberg-Pedersen and Haioty, Moulin and Magalhães do not focus on the passivity of migrant subjects but on their forms of protest. Moreover, they underline the controversial impact of the high increase of Venezuelan migration to Brazil that has led the government to enact a transitory humanitarian migration status.

Overall, authors in this special issue show a variety of ways in which technologies and infrastructures can and are shaping material citizenship politics and migrant subjects' acts of citizenship. The constraining impact is illustrated a) by restricting people's freedom of movement, of welfare and lifestyle choices (Moulin and Magalhães; Esposito et al.) and b) by turning asylum seekers into 'quasi-objects' (Serres 1982) - quite literally, into bodies that provide data that could be extracted, predicted and sold, as well as reify the intersectional biases (Lemberg-Pedersen and Haioty). The overall effect of such technologies and infrastructures is one of creating subjects devoid of power who are treated by the state and institutions along a continuum of dehumanization: from people who are stripped of their agency and voice, to 'surplus/inconvenient population' whose bodies are to be controlled, and - ultimately - to bodies-as-data-containers.

The contestation and participation impact is characterized by ways in which technologies and infrastructures may stimulate the creation of social spaces to reconsider their legitimacy. Van der Kist and Rosset explore the different material processes related to knowledge-production across selected countries and the European Asylum Support Organization (EASO) that establish reliable 'country-of-origin-information', used to define migrants' eligibility to claiming specific protection rights. Their findings contrast authoritative state approaches and more consultative approaches including civil society organization's knowledge claims intending to diversify knowledge to asylum seekers' benefits. The latter approach represents an example of the struggle over the authority of such knowledge infrastructures. The authors argue for acknowledging asylum seekers' and other-than-state-organizations' knowledge claims in these processes which questioning their legitimacy.

The effect of enabling and shaping alternative acts of citizenship is linked to ways in which the very same technologies and infrastructures may create solidarity and affective 
networks (Milivojevic) or become a defining moment in creating collective memories of flight to safety and away from violent conflicts and economic/natural disasters (MoraGamez), thus contributing to identity work.

\section{Concluding remarks}

This article aims to advance the conceptual and analytical repertoire of citizenship studies by further delving into the notion of material citizenship politics. It leverages a focus on the sociomaterial and epistemic practices entangled with technologies and infrastructures, in order to understand how they contribute to shaping multiple forms of political subjectivation of migrants.

As users of autonomy of migration technologies and infrastructures, while also being targeted by migration control technologies and infrastructures, migrants are navigating in a surveillance system where its locus has multiple sites and side effects, from which its sociomaterial conditions cannot be ignored or reified. Therefore, the entanglements of technologies and infrastructures, migrations and citizenship that this volume envisions intends to shed light on the partially contradictory and ambiguous impacts on displaced migrant populations.

Both the contributions to this special issue and their research strategies bring forward the necessity to be reflexive about how we address the researchers' own normative commitments. That is something we want to spell out and what we likewise suggest to consider as an item in its own right for future research. Our normative commitment as critical migration scholars prioritizes as central cue the values and ethics impacting on migrant subjects and their political identities in the processes of sociomaterial and epistemic practices entangled with technologies and infrastructures and how those come with consequences for migrant subjects' ability to acts of citizenship. The contributors to this issue acknowledge the multiplicity of diverse immanent understandings of what social implications of migration and border management are and of what is socially and ethically desirable.

Briefly reflecting on future avenues of research further, we hope to stimulate and advance studies about material citizenship politics in migrations. The contributors to this special issue offer several proposals and tips as to how to further explore such a research agenda. We can suggest our interdisciplinary proposal - start by following the actual trajectories of technologies and infrastructures across their contexts of intervention research. This account can make visible: (1) the types of interactions that people have with and around certain technologies and infrastructures - i.e. most recurrent scripts of action associated with the selected technologies and infrastructures that restrict how they can become enacted and yet may have undervalued potential regarding acts of citizenship; (2) the roles that certain migration control technologies and infrastructures typically assign to different social actors (police officers, migrants, civil service clerks, etc.) in practices when migrant subjects can either comply, contest or resist the status they are assigned by the authorities and their mechanisms; (3) the practices, discourses and sites in which migrant subjects enact technologies and infrastructures in ways that may reveal potential for autonomy of migration.

With this article introducing the special issue, we hope to make a valuable contribution to current debates within critical citizenship studies that focus on the multiple enactments and 
acts of citizenship and that aim to re-define actual notions of the political and political community. Our ambition is also to contribute to setting the research agenda and to stimulate further research along these lines revisiting the (in)visibilities of migrant subjects along technologies and infrastructures. We believe that it is necessary in the current moment of a pandemic emergency, during the present crises and their possible aftermath (as well as to prevent this from happening ever more in the future) - to critically accompany technologies and infrastructures. This critical reflection is instrumental in examining to what extent the technologies and infrastructures affect migrant subjects, and furthermore, in highlighting how the very same technologies and infrastructures may be extended by authoritarian states and political leaders to control the opposing political and civic movements.

\section{Notes}

1. The term 'enactment' has a complex genealogy in theory. In critical citizenship studies, it has become closely linked with performativity and acts and how subjects gain political autonomy through enacting and claiming rights. In that sense, we use the term in relation to migrant subjects' and how they may 'enact' rights. For further reading, we suggest Engin Isin (Isin 2012, 119-146). In STS, however, enactment has been used diversely, but referring in particular to configure the relationality between materiality and human actors, and how technologies and infrastructure may prescribe, through scripts or affordances, how materiality may become enacted by humans. Annemarie Mol's (2003) use of enactment guides us to explore the multiple possible enactments of technologies and infrastructures. For that reason, we wish to clarify that we speak of enactment in a twofold way, either as enactment of political subjectivities and rights to emphasize the abilities of migrant subjects' to gain autonomy or as enactment of technologies and infrastructures which still may occur in multiple forms and with diverse and multiple consequences for migrant subjects.

2. In the third section, the particular notion of agency predominant in STS and Actor-Network -Theory is introduced and further mobilized to specify how migrant subject's capacity is mediated through the symmetry between human and non-human agency.

3. A Foucauldian view would suggest that migrants are managed through a dispositive of migration control, which is a set of discourses, processes, rules, institutions, infrastructures and physical objects enacted to control migration with an underlying philosophical strategy of containment (Foucault 1973). Dispositives imply both physical and nonphysical items and therefore have attracted STS scholars' interest to explore the role of materiality.

4. By using the term of sociomaterial and epistemic practices we focus on those practices entangled with technologies and infrastructures which can be carried out by those contributing to migration control regimes and those contributing to the autonomy of migrant subjects. These practices are considered to come with consequences for migrant subjects' abilities to acts of citizenship.

5. Importantly, this concept is not reducible to any liberal notion of the pure autonomy of migrants as free and sovereign individuals, nor is it a romanticization of the migrant exercise of the freedom of movement as a purely subversive or emancipatory act. Largely inspired by more general autonomist Marxist positions, the autonomy of migration has been conceived in terms of historically specific social formations of human mobility that manifest themselves as a constitutive (subjective, creative and productive) power within the more general capital-labor relation. Moreover, advocates of the autonomy of migration perspective have therefore frequently advanced the proposition that migration can itself be understood to be a social movement in an objective sense. 


\section{Acknowledgments}

We would like to thank Gaia Giuliani who has been among the initiators of this collaboration from the very beginning, and remains an important intellectual inspiration. We are extremely grateful to Peter Nyers for the generous support throughout the production of the special issue and two other anonymous reviewers of this article for the Citizenship Studies journal. Finally, we would like to thank the 12 other anonymous reviewers which were available for a double-blind peer review of the articles involved in this special issue.This article and the special issue it integrates build on a paper workshop organized in Coimbra (2018) by the CES Inter-Thematic Group on Migrations (ITM) and financially supported by the EASST, CES, the EXCHANGE ERC project, and the (DE)OTHERING FCT project. We are thankful to the organizing and supporting entities and to the participants for their fruitful contributions.

\section{Disclosure statement}

No potential conflict of interest was reported by the authors.

\section{Funding}

This work has received funding from the European Research Council (ERC) under the EU Horizon 2020 research and innovation programme (Consolidation grant, agreement No. [648608]), within the project 'EXCHANGE - Forensic geneticists and the transnational exchange of DNA data in the EU: Engaging science with social control, citizenship and democracy', led by Helena Machado and hosted at the Institute for Social Sciences of at the University of Minho, Portugal. Furthermore, this work is funded by the Portuguese Foundation for Science and Technology (FCT/MEC) through national funds within the scope of the CES-SOC/UID/50012/ 2020 Strategic Project.

\section{Notes on contributors}

Nina Amelung is postdoctoral researcher within the ERC-project EXCHANGE on the transnational exchange of forensic DNA data in the EU. She works on public controversies, public involvement and democratic challenges of cross-border biometric data-exchange in the context of crime and migration control infrastructures. She is especially interested in the reflection on emergent publics and participatory devices for non- or contained publics. She has authored and co-authored peer reviewed articles and book chapters on the European asylum policies and biometric technologies applied in migration control infrastructures.

Cristiano Gianolla is a researcher at the Centre for Social Studies (CES) of the University of Coimbra, Portugal. He integrates the research team of the project ECHOES (H2020, 2018-2021) and previously ALICE (ERC, 2011-2016). His main research interest lay on democratic theory, intercultural dialogue, populism, citizenship, postcolonialism, cosmopolitanism, human rights, and migrations. He authored two books and a number of scientific articles. He is a founding member of the Inter-Thematic group on Migrations (ITM) at CES.

Olga Solovova is postdoctoral researcher at the MultiLing, University of Oslo, Norway.Her project looks into discourses in action on the Norwegian-Russian border, and the role of Russian in the bordering practices within the multilingual economy. Her main fields of expertise are language ideologies and policies in multilingual and migrant contexts, social construction of space and multimodal meaning making, spaces and means of representation of the Other. She has authored and co-authored book chapters and articles on media representations of migrant and refugee population, language policies in migrant contexts and in academy. 
Joana Sousa Ribeiro is a researcher at Centre for Social Studies (NHUMEP Research GroupHumanities,Migration and Peace Studies Research) and a PhD student at the School of Economics, University of Coimbra. Her main research interests include socio-professional mobility of migrants and refugees, longitudinal studies, intercultural studies and citizenship. She co-cordinates an IMISCOE research network group - YAMEC Network - that focuses on issues of mobility of young adults and the economic crisis and she is a founding member of the Inter-Thematic group on Migrations (ITM) at CES.

\section{ORCID}

Nina Amelung (D) http://orcid.org/0000-0002-2195-6955

Cristiano Gianolla (D) http://orcid.org/0000-0002-2809-0453

Olga Solovova (iD http://orcid.org/0000-0003-3481-5323

Joana Sousa Ribeiro (D) http://orcid.org/0000-0002-5779-7503

\section{References}

Ahearn, L. M. 2001. "Language and Agency." Annual Review of Anthropology 30 (1): 109-137. doi:10.1146/annurev.anthro.30.1.109.

Amoore, L. 2006. "Biometric Borders: Governing Mobilities in the War on Terror." Political Geography 25 (3): 336-351. doi:10.1016/j.polgeo.2006.02.001.

Ataç, I., K. Rygiel, and M. Stierl. 2016. "Introduction: The Contentious Politics of Refugee and Migrant Protest and Solidarity Movements: Remaking Citizenship from the Margins." Citizenship Studies 20 (5): 527-544. doi:10.1080/13621025.2016.1182681.

Bloor, D. 1991. Knowledge and Social Imagery: Second Edition. 1 ed. Chicago: University of Chicago Press.

Bowker, G. C., and S. L. Star. 1999. Sorting Things Out: Classification and Its Consequences. New Edition ed. Cambridge MA and London: MIT Press.

Brenner, N. 1999. "Globalisation as Reterritorialisation: The Re-Scaling of Urban Governance in the European Union.” Urban Studies 36 (3): 431-451. doi:10.1080/0042098993466.

Callon, M. 1986. "Some Elements of a Sociology of Translation. Domestication of the Scallops and the Fishermen of St. Brieuc Bay.” In Power, Action, and Belief: A New Sociology of Knowledge?, edited by J. Law, 196-233. London: Routledge \& Kegan Paul.

Caraus, T. 2018. "Migrant Protests as Acts of Cosmopolitan Citizenship." Citizenship Studies 22 (8): 791-809. doi:10.1080/13621025.2018.1530194.

Casas-Cortes, M., S. Cobarrubias, N. De Genova, G. Garelli, G. Grappi, C. Heller, S. Hess, et al. 2015. "New Keywords: Migration and Borders." Cultural Studies 29 (1): 55-87. doi:10.1080/ 09502386.2014.891630.

Couldry, N., H. Stephansen, A. Fotopoulou, R. MacDonald, W. Clark, and L. Dickens. 2014. "Digital Citizenship? Narrative Exchange and the Changing Terms of Civic Culture." Citizenship Studies 18 (6-7): 615-629. doi:10.1080/13621025.2013.865903.

Dewey, J. 1990. "Review of Public Opinion by Walter Lippmann.” In The Middle Works of John Dewey, 1899-1924, Vol. 13. Essays in Philosophy, Education and the Orient, 1921?1922, edited by J. A. Boydston, 13:337-44. 1st ed. Carbondale: Southern Illinois University Press.

Dijstelbloem, H., and A. Meijer, eds. 2011. Migration and the New Technological Borders of Europe. Migration, Minorities and Citizenship. London: Palgrave Macmillan UK. doi:10.1057/ 9780230299382.

Dijstelbloem, H., and D. Broeders. 2015. "Border Surveillance, Mobility Management and the Shaping of Non-Publics in Europe." European Journal of Social Theory 18 (1): 21-38. doi:10.1177/1368431014534353. 
Esposito, F., J. Ornelas, E. Briozzo, and C. Arcidiacono. 2019. "Ecology of Sites of Confinement: Everyday Life in a Detention Center for Illegalized Non-Citizens." American Journal of Community Psychology 63 (1-2): 190-207. doi:10.1002/ajcp.12313.

Foucault, M. 1973. The birth of the clinic: An archaeology of medical perception. London: Tavistock. Hughes, S. M., and P. Forman. 2017. "A Material Politics of Citizenship: The Potential of Circulating Materials from UK Immigration Removal Centres.” Citizenship Studies 21 (6): 675-692. doi:10.1080/13621025.2017.1341659.

Isin, E. F. 2008. “Theorizing Acts of Citizenship.” In Acts of Citizenship, edited by E. F. Isin and G. M. Nielsen, 15-43. London and New York: Zed Books.

Isin, E. F. 2009. "Citizenship in Flux: The Figure of the Activist Citizen." Subjectivity 29 (1): 367-388. doi:10.1057/sub.2009.25.

Isin, E. F. 2012. "Citizenship after Orientalism: An Unfinished Project." Citizenship Studies 16 (5-6): 563-572. doi:10.1080/13621025.2012.698480.

Isin, E. F. 2019. "Doing Rights with Things: The Art of Becoming Citizens." In Performing Citizenship. Performance Philosophy, edited by P. Hildebrandt, K. Evert, S. Peters, M. Schaub, K. Wildner, and G. Ziemer, 45-56. Cham: Palgrave Macmillan.

Isin, E. F., and B. Turner. 2002. Handbook of Citizenship Studies. London: Sage Publications. doi:10.4135/9781848608276.

Jacobsen, K. L. 2015. The Politics of Humanitarian Technology: Good Intentions, Unintended Consequences and Insecurity. 1 ed. London and New York: Routledge.

Jessop, B. 1994. "Post-Fordism and the State." In Post-Fordism, edited by A. Amin, 251-279. Oxford; Malden: Blackwell Publishers Ltd., doi:10.1002/9780470712726.ch8.

Knorr-Cetina, K. 1981. The Manufacture of Knowledge. Oxford: Pergamon. doi:10.1016/C20090-09537-3.

Larkin, B. 2013. “The Politics and Poetics of Infrastructure." Annual Review of Anthropology 42 (1): 327-343.

Latonero, M., and P. Kift. 2018. "On Digital Passages and Borders: Refugees and the New Infrastructure for Movement and Control." Social Media + Society 4: 1. doi:10.1177/ 2056305118764432.

Latour, B., and S. Woolgar. 1986. Laboratory Life: The Construction of Scientific Facts, 2nd. 2nd ed. Princeton NJ: Princeton University Press.

Law, J. 2004. After Method: Mess in Social Science Research. 1 ed. London: Routledge.

Lewicki, A. 2017. ““The Dead are Coming”: Acts of Citizenship at Europe's Borders.” Citizenship Studies 21 (3): 275-290. doi:10.1080/13621025.2016.1252717.

Lippmann, W. 1997. Public Opinion. Reissue edition ed. New York: Free Press.

Lynch, M. E., and S. Woolgar, eds. 1990. Representation in Scientific Practice. 1 ed. Cambridge MA: MIT Press.

M'charek, A., and S. Casartelli. 2019. "Identifying Dead Migrants: Forensic Care Work and Relational Citizenship.” Citizenship Studies 23 (7): 738-757. doi:10.1080/13621025.2019.1651102.

Maestri, G., and S. M. Hughes. 2017. "Contested Spaces of Citizenship: Camps, Borders and Urban Encounters." Citizenship Studies 21 (6): 625-639. doi:10.1080/13621025.2017.1341657.

Marres, N. 2012. Material Participation: Technology, the Environment and Everyday Publics. 2012 Edition. Basingstoke: Palgrave Macmillan.

Marres, N., and J. Lezaun. 2011. "Materials and Devices of the Public: An Introduction." Economy and Society 40 (4): 489-509. doi:10.1080/03085147.2011.602293.

Mezzadra, S. 2011. “The Gaze of Autonomy: Capitalism, Migration and Social Struggles". In The Contested Politics of Migration, edited by V. Squire, 121-142. New York: Routledge.

Mezzadra, S. 2017. "Digital Mobility, Logistics, and the Politics of Migration." Spheres: Journal for Digital Cultures 4: 1-4. doi:10.25969/mediarep/3855.

Milan, S., A. Pelizza, and Y. Lausberg. 2020. "Making Migrants Visible to COVID-19 Counting: The Dilemma." OpenDemocracy, April 28. https://www.opendemocracy.net/en/can-europemake-it/making-migrants-visible-covid-19-counting-dilemma/

Mol, A. 2003. The Body Multiple: Ontology in Medical Practice. Durham and London: Duke University Press. 
Monforte, P. 2016. "The Border as a Space of Contention: The Spatial Strategies of Protest against Border Controls in Europe." Citizenship Studies 20 (3-4): 411-426. doi:10.1080/ 13621025.2015.1075471.

Moulin, C., and D. Thomaz. 2016. 'The tactical politics of "Humanitarian" immigration: Negotiating stasis, enacting mobility'. Citizenship Studies 20 (5): 595-609. https://doi.org/ 10.1080/13621025.2016.1182679.

Netz, S., S. Lempp, K. Krause, and K. Schramm. 2019. "Claiming Citizenship Rights through the Body Multiple." Citizenship Studies 23 (7): 637-651. doi:10.1080/13621025.2019.1651041.

Nyers, P. 2015. "Migrant Citizenships and Autonomous Mobilities." 1 (1): 23-39. doi:10.18357/ mmd11201513521.

Oliveri, F. 2012. "Migrants as Activist Citizens in Italy: Understanding the New Cycle of Struggles.” Citizenship Studies 16 (5-6): 793-806. doi:10.1080/13621025.2012.698509.

Papadopoulos, D. 2010. “Alter-Ontologies: Towards a Constituent Politics in Technoscience." Social Studies of Science 41 (2): 177-201. doi:10.1177/0306312710385853.

Papadopoulos, D., and V. S. Tsianos. 2013. "After Citizenship: Autonomy of Migration, Organisational Ontology and Mobile Commons." Citizenship Studies 17 (2): 178-196. doi:10.1080/13621025.2013.780736.

Pelizza, A. 2019.“Processing Alterity, Enacting Europe: Migrant Registration and Identification as Co-Construction of Individuals and Polities." Science, Technology, \& Human Values February. doi:10.1177/0162243919827927.

Pollozek, S., and J. H. Passoth. 2019. "Infrastructuring European Migration and Border Control: The Logistics of Registration and Identification at Moria Hotspot." Environment and Planning D: Society and Space 37 (4): 606-624. doi:10.1177/0263775819835819.

Rygiel, K. 2011. "Bordering Solidarities: Migrant Activism and the Politics of Movement and Camps at Calais.” Citizenship Studies 15 (1): 1-19. doi:10.1080/13621025.2011.534911.

Rygiel, K. 2016. "Dying to Live: Migrant Deaths and Citizenship Politics along European Borders: Transgressions, Disruptions, and Mobilizations." Citizenship Studies 20 (5): 545-560. doi:10.1080/13621025.2016.1182682.

Santos, B. D. S. 2014. Epistemologies of the South: Justice against Epistemicide. Boulder: Paradigm Publishers.

Santos, B. D. S. 2018. The End of the Cognitive Empire: The Coming of Age of Epistemologies of the South. Durham: Duke University Press.

Scheel, S. 2013. "Studying Embodied Encounters: Autonomy of Migration beyond Its Romanticization." Postcolonial Studies 16 (3): 279-288. doi:10.1080/13688790.2013.850046.

Scheel, S. 2019. Autonomy of Migration?: Appropriating Mobility within Biometric Border Regimes. 1 edizione ed. Abingdon, Oxon and New York: Routledge.

Serres, M. 1982. "Theory of the Quasi-object." In The Parasite, edited by Schehr LR, 224-234. Baltimore: John Hopkins University Press.

Snodgrass, E. 2017. "Executions: Power and Expression in Networked and Computational Media." Dissertation, Malmö University. http://muep.mau.se/handle/2043/22834

Stierl, M. 2016. "A Sea of Struggle - Activist Border Interventions in the Mediterranean Sea." Citizenship Studies 20 (5): 561-578. doi:10.1080/13621025.2016.1182683.

Tambakaki, P. 2015. 'Citizenship and inclusion: Rethinking the analytical category of noncitizenship'. Citizenship Studies 19 (8): 922-35. https://doi.org/10.1080/13621025.2015.1110285.

Tazzioli, M. 2018. "Crimes of Solidarity." Radical Philosophy 2 (1): 1-7.

Tazzioli, M., and N. De Genova. 2015. "Europe/Crisis: Introducing New Keywords of "the Crisis" in and of "Europe"”. Europe at a Crossroad. http://nearfuturesonline.org/europecrisis-newkeywords-of-crisis-in-and-of-europe/

Tazzioli, M., and W. Walters. 2019. "Migration, Solidarity and the Limits of Europe." Global Discourse, no. 9: 175-190. doi:10.1332/204378918X15453934506030.

Tonkiss, K., and T. Bloom. 2015. 'Theorising noncitizenship: Concepts, debates and challenges'. Citizenship Studies 19 (8): 837-52. https://doi.org/10.1080/13621025.2015.1110278.

Topak, Ö. E. 2017. "Migrant Protest in Times of Crisis: Politics, Ethics and the Sacred from Below.” Citizenship Studies 21 (1): 1-21. doi:10.1080/13621025.2016.1191428. 
Turner, J. 2016. “(En)gendering the Political: Citizenship from Marginal Spaces.” Citizenship Studies 20 (2): 141-155. doi:10.1080/13621025.2015.1132569.

Tyler, I., and K. Marciniak. 2013. "Immigrant Protest: An Introduction." Citizenship Studies 17 (2): 143-156. doi:10.1080/13621025.2013.780728.

Voß, J.-P., and R. Freeman. 2016. Introduction: Knowing Governance. In Knowing Governance. Palgrave Studies in Science, Knowledge and Policy, edited by Voß JP., Freeman R, 1-34. London: Palgrave Macmillan.

Walters, W. 2014. "Migration, Vehicles, and Politics: Three Theses on Viapolitics." European Journal of Social Theory 18 (4): 469-488. doi:10.1177/1368431014554859.

Walters, W. 2017. "Aviation as Deportation Infrastructure: Airports, Planes, and Expulsion." Journal of Ethnic and Migration Studies 44 (16): 2796-2817. doi:10.1080/ 1369183X.2017.1401517.

Xiang, B., and J. Lindquist. 2014. “Migration Infrastructure.” International Migration Review 48 (1): 122-148. doi:10.1111/imre.12141.

Yuval-Davis, N. 2006. "Belonging and the Politics of Belonging." Patterns of Prejudice 40 (3): 197-214. doi:10.1080/00313220600769331. 